\title{
STUDI PEMANFAATAN TEKNOLOGI TERRESTRIAL LASER SCANNER UNTUK MENGHITUNG VOLUME PENGUPASAN OVERBURDEN DI PIT 2 ELEKTRIFIKASI BANKO BARAT PT. BUKIT ASAM, TBK. TANJUNG ENIM, SUMATERA SELATAN
}

\author{
STUDY OF TERRESTRIAL LASER SCANNER \\ TECHNOLOGY UTILIZATION TO CALCULATE THE \\ STRIPPING VOLUME OF OVERBURDEN IN PIT 2 \\ ELECTRIFICATION MINING, BANKO BARAT, PT. BUKIT \\ ASAM, TBK., TANJUNG ENIM, SUMATERA SELATAN.
}

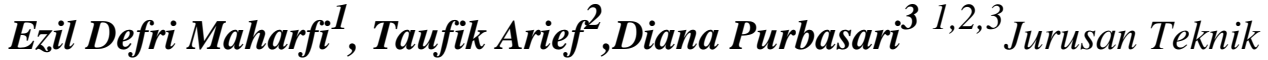 \\ Pertambangan, Fakultas Teknik, Universitas Sriwijaya Jl. Raya Palembang- \\ Prabumulih Km.32 Inderalaya Sumatera Selatan, Indonesia Email : \\ defrizil@gmail.com
}

\begin{abstract}
ABSTRAK
PT. Bukit Asam, Tbk. merupakan perusahaan pertambangan batubara yang terletak di Tanjung Enim, Kabupaten Muara Enim, Provinsi Sumatera Selatan. Selama ini pengukuran volume pengupasan overburden dilakukan menggunakan alat Total Station. Pengukuran area overburden yang luas dan bentuk permukaan yang beragam menggunakan Total Station dinilai kurang efektif karena lamanya waktu yang dibutuhkan dan rendahnya tingkat ketelitian. Oleh kerena itu, diperlukan alat yang dapat mengukur volume dengan cepat serta menghasilkan data ukuran volume yang detail dan dengan kerapatan tinggi. Salah satunya yaitu penggunaan Terrestrial Laser Scanner. Metode yang digunakan dalam melakukan pengukuran yaitu metode occupation and backsight. Pengukuran menggunakan metode occupation and backsight diperlukan dua titik yang telah diketahui koordinatnya yang digunakan sebagai titik berdiri alat dan untuk titik acuan (backsight). Metode registrasi yang digunakan yaitu metode occupation and backsight dan metode cloud to cloud. Data point clouds yang telah diregistrasi perlu dilakukan filtering untuk menghilangkan noise dan objek asing yang bukan lapisan overburden. Perhitungan volume dilakukan dengan metode cut and fill terhadap model tiga dimensi dari point cloud yang terbentuk. Data hasil perhitungan didapatkan volume pengupasan overburden selama Desember 2017 sampai dengan Mei 2018 adalah sebesar $847.937 \mathrm{~m}^{3}$, dengan rincian $255.700 \mathrm{~m}^{3}$ di bulan Desember 2017, $299.120 \mathrm{~m}^{3}$ di bulan Januari 2018, $227.543 \mathrm{~m}^{3}$ di Bulan Februari 2018 dan $65.572 \mathrm{~m}^{3}$ di bulan Maret 2018.

Kata Kunci : Terrestrial Laser Scanner, overburden, Registrasi
\end{abstract}




\begin{abstract}
PT. Bukit Asam, Tbk. is a coal mining company located in Tanjung Enim, Muara Enim District, South Sumatra. The measurement area and extensive overburden form a diverse surface using a Total Station is judged less effective because of the length of time required and low levels of precision. It's a necessary tool that can measure the volume quickly and generate a data volume size that detail and with high density. One of them, namely the use of Terrestrial Laser Scanner. The methods used in conducting the measurement method occupation and backsight. Measurement method using occupation and backsight needed two points which have been known to its own coordinate used as tools and stand point to a reference point (backsight). Data point clouds that had been registered to do filtering to eliminate noise and foreign objects not layers of overburden. Calculation of the volume done by the method of cut and fill a three-dimensional model of toward point cloud formed. Data calculation result obtained by the volume of stripping overburden duringDecember 2017 up to May 2018 amounted to $847,937 \mathrm{~m}^{3}$, with details of 255,700 $\mathrm{m}^{3}$ in December 2017, 299,120 $\mathrm{m}^{3}$ in January 2018, 227,543 $\mathrm{m}^{3}$ in February 2018 and 65,572 $\mathrm{m}^{3}$ in March 2018.
\end{abstract}

Keywords : Terrestrial Laser Scanner, overburden, registration

\title{
1. PENDAHULUAN
}

Perkembangan dunia survei dan pemetaan sangatlah pesat. Di era sekarang ini, pemanfaatan teknologi Terestrial Laser Scanner dapat memberikan solusi untuk pendokumentasian suatu bangunan, topografi bahkan volume suatu tumpukan. Teknologi ini dinilai sangat efisien jika dibandingkan dengan teknologi pengukuran lainnya. Hasil pengukuran Terestrial Laser Scanner berupa point cloud yang mempunyai koordinat 3 dimensi. Perhitungan volume lapisan overburden bisa dilakukan menggunakan Terestrial Laser Scanner ini dengan cepat. Jika dibandingkan dengan alat ukur lainnya, Terestrial Laser Scanner memiliki tingkat akurasi yang lebih tinggi serta waktu pengoperasian yang jauh lebih efektif dan efisien. Sehingga penggunaan Terestrial Laser Scanner sebagai alat ukur penambangan di era modern ini sangatlah menguntungkan, baik dari segi ekonomis maupun dari segi efektifitas waktu yang digunakan.

Perhitungan estimasi volume pengupasan overburden dengan alat konvensional, seperti Theodolite, Total Station dan GPS Geodetik memiliki permasalahan utama, yaitu teknologi perhitungan yang masih menerapkan metode human plotting, artinya surveyor harus menuju titik yang diinginkan untuk memperoleh data koordinat, sehingga waktu yang dibutuhkan tentu lebih banyak. Berbeda dengan Terestrial Laser Scanner, alat ini menggunakan teknologi laser untuk mendapatkan data koordinat, bahkan mampu memperoleh $>1.000 .000$ titik dalam satu kali pemindaian, sehingga jauh lebih efektif dan efisien dari segi waktu maupun pekerjaan.

PT. Bukit Asam, Tbk. pada tahun 2018 menargetkan produksi batubara sebesar 27,7 juta ton, artinya dengan Stripping Ratio 4, maka perusahaan harus mengupas 110,8 juta BCM overburden pada tahun yang sama. Melihat tingginya kapasitas produksi 
overburden yang harus dicapai, maka penggunaan teknologi Terestrial Laser Scanner sangat layak diterapkan perusahaan. Hal ini bertujuan untuk mempersingkat waktu pekerjaan survei sehingga perhitungan volume overburden menjadi lebih cepat pula.

Penelitian ini akan membahas perhitungan volume pengupasan lapisan overburden dengan melakukan kegiatan survei menggunakan alat ukur Terestrial Laser Scanner di Pit 2 Elektrifikasi Banko Barat, PT. Bukit Asam, Tbk. Data yang telah diambil dan terkumpul (data collect) akan diproses menggunakan software Maptek I-Site dan RiScan Pro, sehingga nantinya dapat diwujudkan dalam bentuk gambar tiga dimensi (3D) serta dapat dihitung volume pengupasan overburden tiap bulannya.

\subsection{Tujuan}

Tujuan dari penelitian ini adalah sebagai berikut:

1. Menganalisis aplikasi Terrestrial Laser Scanner sebagai media pengambilan data survei untuk menghitung volume pengupasan overburden.

2. Mengetahui proses pengolahan data hasil pengukuran Terestrial Laser Scanner menjadi data gambar tiga dimensi (3D) menggunakan software Maptek I-Sitedan RiScan Pro.

3. Menganalisis perhitungan volume pengupasan overburden berdasarkan data survei Terestrial Laser Scanner menggunakan software Maptek ISitedanRiScan Pro.

4. Mengetahui perbedaan pengukuran menggunakan Terrestrrial Laser Scanner dengan Total Station.

\subsection{Terrestrial Laser Scanner}

Terrestrial Laser Scanner merupakan suatu peralatan penangkapan gambar (image) aktif yang secara cepat dapat memperoleh kumpulan dari titik-titik tiga dimensi dari suatu objek maupun permukaan (Lichti, 2005).

Terdapat dua jenis scanner berdasarkan prinsip pengoperasiannya, yaitu (Boehler,2002):

1. Triangulation Scanners

Terdiri dari single camera solution dan double camera solution.

2. Ranging Scanners

a. Time of flight of a laser pulse. Laser dipancarkan ke objek selanjutnya jarak dihitung dari waktu perjalanan antara sinyal transmisi dan penerimaannya. Prinsip ini mempunyai akurasi rendah karena merupakan tipe scanner jarak jauh dengan cakupan 1,5 - 6.000 meter. Scanner jenis ini cepat dalam melakukan akuisisi data dan titik yang didapat hingga mencapai 11.000 - 122.000 titik setiap detiknya.

b. Phase comparison method. Metode ini juga sering dikenal melalui alat tacheometric. Laser yang dipancarkan dimodulasikan dengan gelombang harmonik dengan jarak yang dihitung dengan menggunakan perbedaan beda fase antara gelombang pancar dan gelombang yang diterima. Akurasi yang dihasilkan rendah karena merupakan tipe scanner jarak menengah. Akan tetapi, scanner jenis ini dapat mengukur hingga 1.000.000 titik setiap detiknya. 


\subsection{Prinsip Pengukuran Terrestrial Laser Scanner}

Pada pengukuran menggunakan TLS dengan melakukan pemindaian objek target, maka didapat hasil berupa point clouds yang memiliki koordinat tiga dimensi. Untuk mendapatkan sebaran titik tersebut dilakukan dengan menggunakan gelombang yang dipancarkan dan diterima kembali oleh alat dengan mengukur sudut serta jarak antara sensor dengan objek. Jenis gelombang yang digunakan dalam TLS yaitu gelombang laser sehingga dapat digunakan untuk mengukur jarak.

Agar dapat diperoleh point cloud dengan koordinat tertentu maka terlebih dahulu menentukan jarak. Salah satu prinsip kerja TLS yaitu menggunakan prinsip pulse based dimana pengukuran yang didasarkan pada waktu tempuh gelombang laser mulai dari laser dipancarkan hingga diterima kembali oleh penerima pulsa laser.

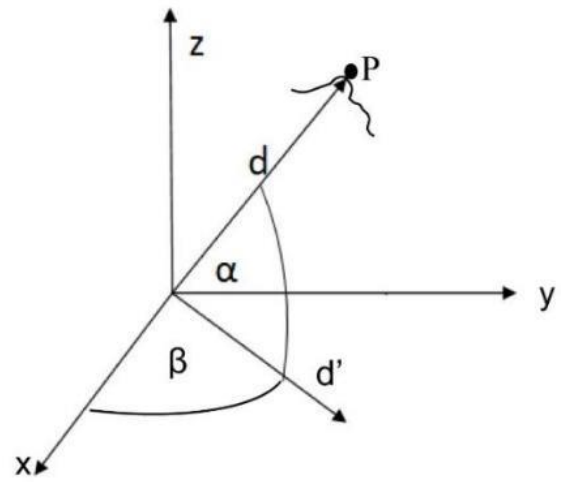

Gambar 1. Penentuan koordinat tiga dimensi point clouds(Hai, 2008)

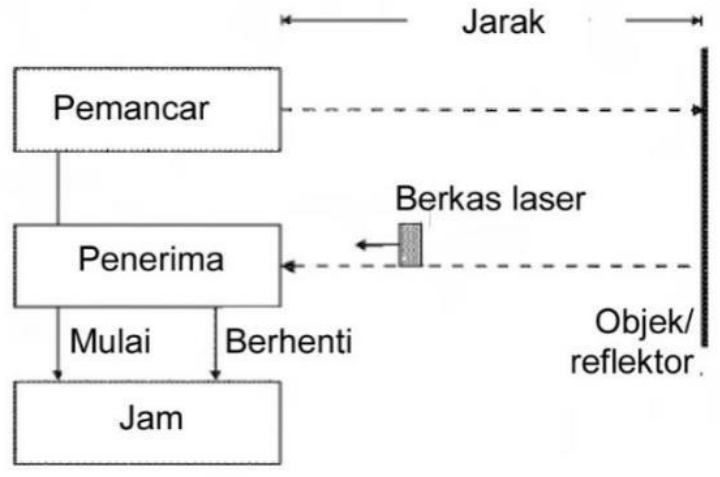

Gambar 2. Pengukuran jarak menggunakan prinsip waktu tempuh berkas cahaya (Zetsche, 1979)

\subsection{Registrasi Data}

Pengambilan data dengan laser scanner untuk objek tiga dimensi tidak mungkin dapat dilakukan hanya dengan satu kali pengambilan data, sehingga diperlukan teknik untuk menggabungkan data-data per satu kali pengambilan (ScanWorld) ke dalam sebuah data global yang dikenal dengan nama registrasi. 

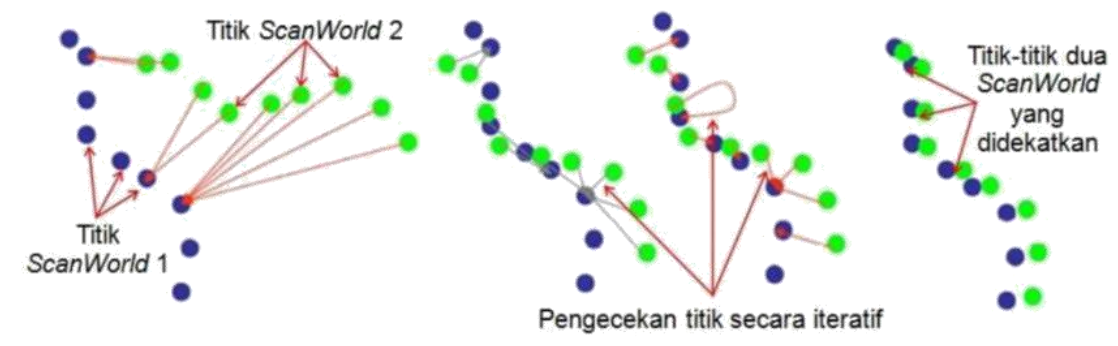

\section{Gambar 3. Registrasi Cloud to Cloud}

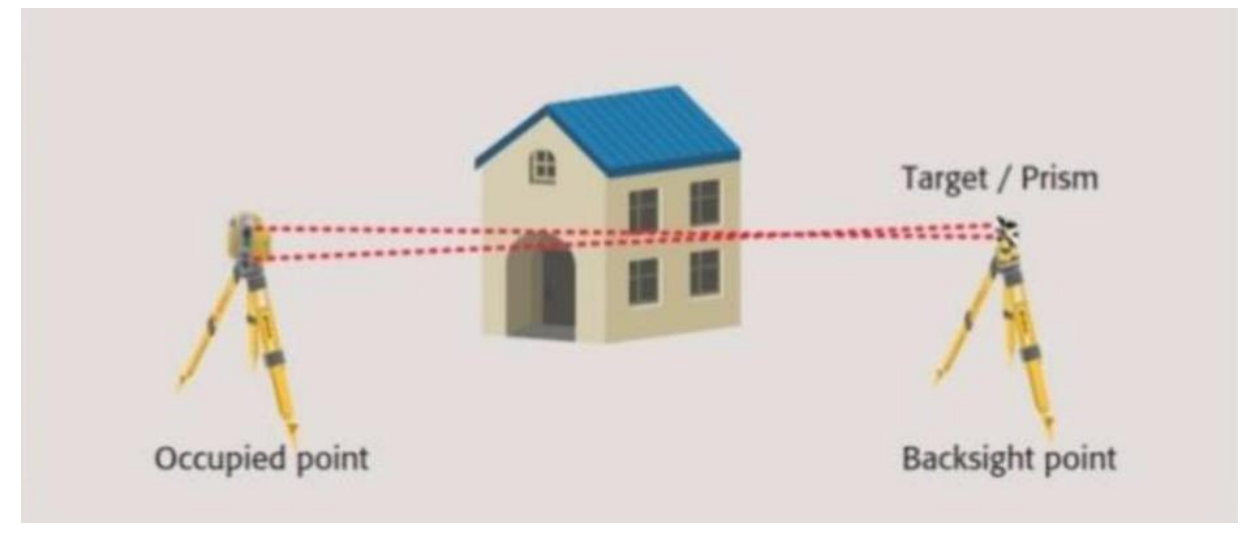

Gambar 4. Registrasi Occupation and Backsight

\subsection{Metode Perhitungan Estimasi Volume Pengupasan Overburden}

Perhitungan volume overburden pada Terrestrial Laser Scanner maupun pada alat ukur lainnya seperti Waterpass, Theodolite dan Total Station menerapkan metode triangulasi, dimana metode ini merupakan bagian dari perhitungan volume endapan metode Penampang Horizontal (Hustrulid and Kutcha 1995). Metode Triangulasi dilakukan dengan konsep dasar menjadikan titik yang diketahui menjadi titik sudut suatu prisma segitiga. Prisma segitiga diperoleh dengan cara menghubungkan titik-titik yang diketahui tanpa berpotongan.

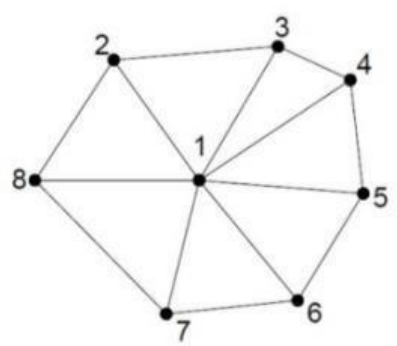

Layout dari segitiga-segitiga

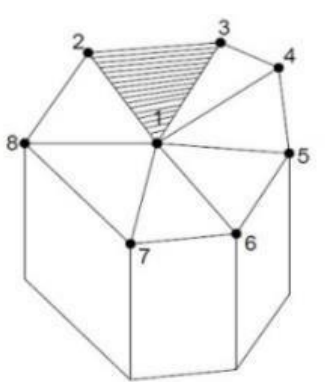

Prisma-prisma trianguler

Gambar 5. Prinsip perhitungan volume overburden

\section{METODE PENELITIAN}

Metode yang digunakan dalam prose perekaman data tiga dimensi (3D) 
menggunakan Laser Scanner dibagi menjadi 4 tahap, yang terdiri dari :

\subsection{Persiapan}

Pada tahap persiapan awal penelitian ini kegiatan yang dilakukan meliputi studi pustaka/literatur terkait objek yang menjadi sasaran perekaman data. Tahapan persiapan merupakan tahapan utama dalam suatu pengukuran yang bertujuan untuk mempermudahkan pengambilan data saat di lapangan. Tahapan persiapan terdiri dari persiapan personil dan persiapan peralatan. Tahapan persiapan memberikan gambaran tentang hal-hal penting pada bagian apa saja yang harus direkam secara lebih detail.

\subsection{Perekaman Data di Lapangan}

Merupakan tahapan yang dilakukan pada obyek penelitian yaitu padapit 2 Elektrifikasi Penambangan Banko Barat, PT. Bukit Asam, Tbk., Tanjung Enim, Sumatera Selatan. Dalam tahapan perekaman data dilapangan ini dibagi menjadi beberapa aktivitas yaitu :

a. Survey lokasi untuk penentuan titik berdiri alat

b. Proses perekaman data (pemindaian tiga dimensi (3D)

\subsection{Pengolahan Data}

Proses pengolahan data dilakukan di lapangan dan di laboratorium. Pengolahan data di lapangan sebagai koreksi awal apabila ada data yang kurang, sehingga bisa cepat dilengkapi dan proses selanjutnya yaitu pengolahan data di laboratorium. Pengolahan data di laboratorium menggunakan komputer berpeforma tinggi untuk menjalan program RiScan Pro, Qgis dan Maptek I-Site. Tahap pengolahan data terdiri dari proses registrasi, georeferensi, filtering dan proses pembuatan data tiga dimensi (3D).

\subsection{Analisis Data}

Dari pengolahan data tiga dimensi (3D) hasil perekaman, kemudian dilakukan analisis obyek untuk menghitung volume pengupasan overburden berdasarkan cut and fill pengupasan overburden.

\section{HASIL DAN PEMBAHASAN}

\subsection{Pengaplikasian Terrestrial Laser Scanner dalam Pengambilan Data Survei} Data hasil pengukuran Terestrial Laser Scannertiap satu kali melakukan pemindaian dinamakan Scanworld. Scanworld berisi kumpulan titik-titik yang telah diketahui koordinatnya yang disebut dengan point cloud. Penentuan koordniat point cloud didasarkan pada koordinat berdiri alat sebagai titik kontrol. Pengukuran koordinat stasiun berdiri alat diukur menggunakan Total Station. 
Tabel 1. Koordinat stasiun berdiri alat dengan sistem UTM WGS 1984 zona 48s

\begin{tabular}{lccc}
\hline \multicolumn{4}{c}{ Pengukuran Maret 2018 } \\
\hline Nama Titik & $\mathbf{X}$ & $\mathbf{Y}$ & $\mathbf{Z}$ \\
\hline 23.c (backsight) & 369293.5640 & 9581978.3440 & 67.3570 \\
b1.18 & 369279.5340 & 9581984.1010 & 66.5980 \\
p2.a & 368779.7004 & 9581631.0678 & 68.7422 \\
p2.b & 368878.5904 & 9581835.7158 & 41.4043 \\
p2.c & 368967.5181 & 9582074.5364 & 52.7432 \\
p2.d & 369136.6025 & 9582086.2871 & 62.5367 \\
\hline
\end{tabular}

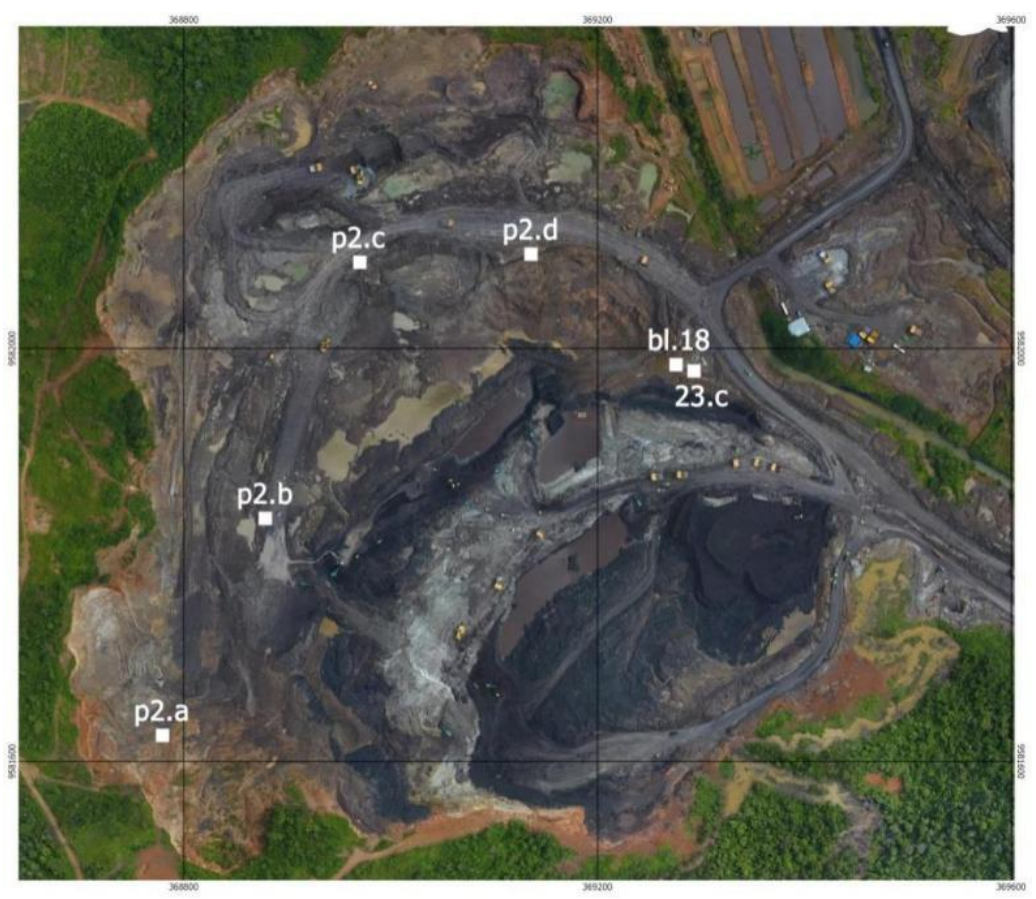

Gambar 6. Posisi berdiri Terrestrial Laser Scanner dilihat dari foto citra udara

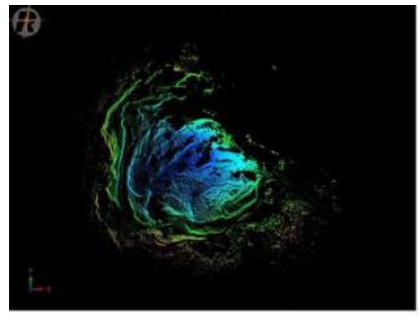

bl.18

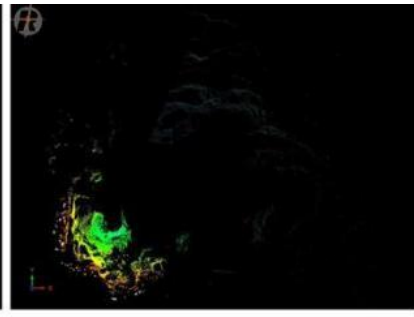

p2.a

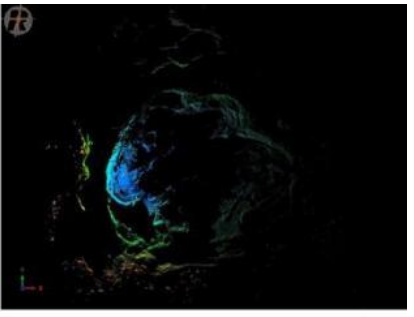

p2.b

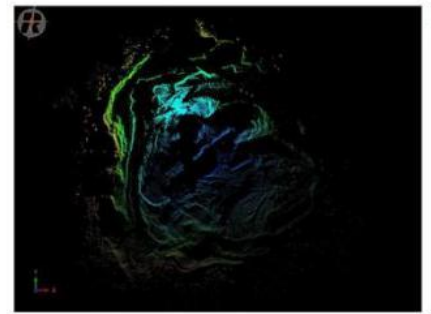

p2.c

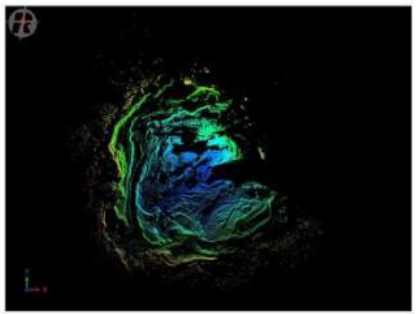

p2.d

Gambar 7. Hasil pindaian tiap berdiri alat (scanworld) 


\subsection{Pengolahan Data Hasil Pengukuran Terrestrial Laser Scanner menjadi Data Tiga Dimensi (3D)}

Hasil pengukuran Terrestrial Laser Scanner adalah data point clouds yang belum dapat dijadikan acuan dalam perhitungan volume pengupasan overburden. Oleh sebab itu, data point clouds harus diolah dengan menggunakan software Maptek ISite, QGis dan Riscan Pro sehingga nantinya menjadi data valid yang bisa menjadi acuan dalam proses perhitungan volume.

Proses registrasi dilakukan dengan tujuan untuk menggabungkan seluruh data pindaian (scanwolrd) pada tiap stasiun pengukuran menjadi satu data surface yang telah mencakup seluruh area pengukuran. Metode yang diterapkan pada proses registrasi ini adalah metode "occupation \& backsigh" dan metode "cloud to cloud".

Georeferensi merupakan proses transformasi koordinat lokal keseluruhan point cloud ke dalam sistem koordinat yang diinginkan (dalam kasus ini adalah koordinat WGS 1984 UTM zona 48S) dapat dilakukan hanya dengan menentukan parameter transformasi pada saat memasukkan data pengukuran ke dalam program RiScan Pro.

Proses filtrasi bertujuan untuk menghapus objek-objek asing, seperti alat berat, mobil, manusia, vegetasi dan lain sebagainya yang dapat mempengaruhi hasil pengukuran. Hal ini berdampak juga pada hasil akhir perhitungan volume pengupasan overburden. Proses filtrasi dapat dilakukan dalam dua cara, yaitu pada saat data masih dalam bentuk point clouds dan pada saat data sudah dalam bentuk TIN (tiga dimensi).

Pemodelan tahap akhir merupakan pemodelan data point cloud yang telah menjalani proses registrasi, georeferensi dan filtrasi dengan baik sehingga bentuk surface 3D dari model ini akan sama dengan keadaan nyata di lapangan dengan persentase kesamaan $\geq 80 \%$. Hasil pemodelan data point cloud ini merupakan dasar acuan dalam perhtiungan volume pengupasan overburden.

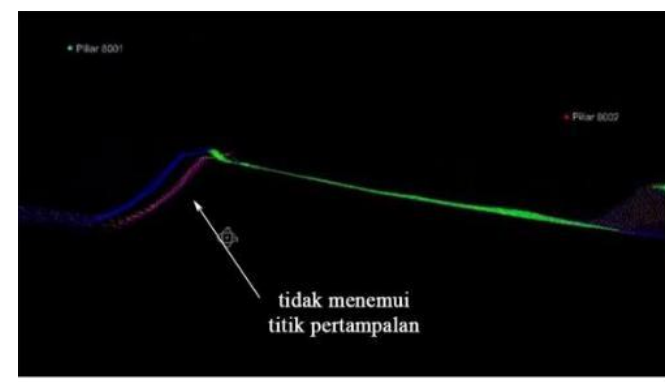

Sebelum Fine Registrasi

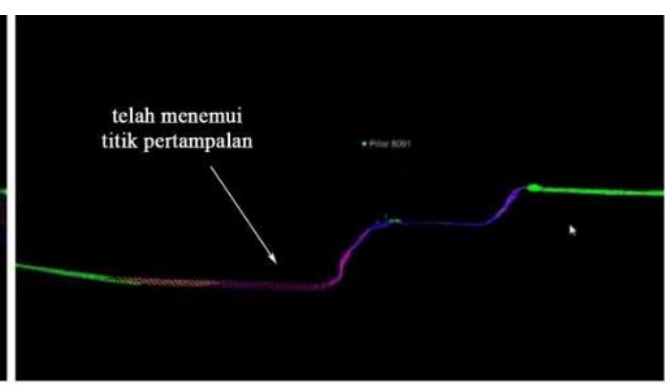

Sesudah Fine Registrasi

Gambar 8. Hasil proses registrasi data point clouds 


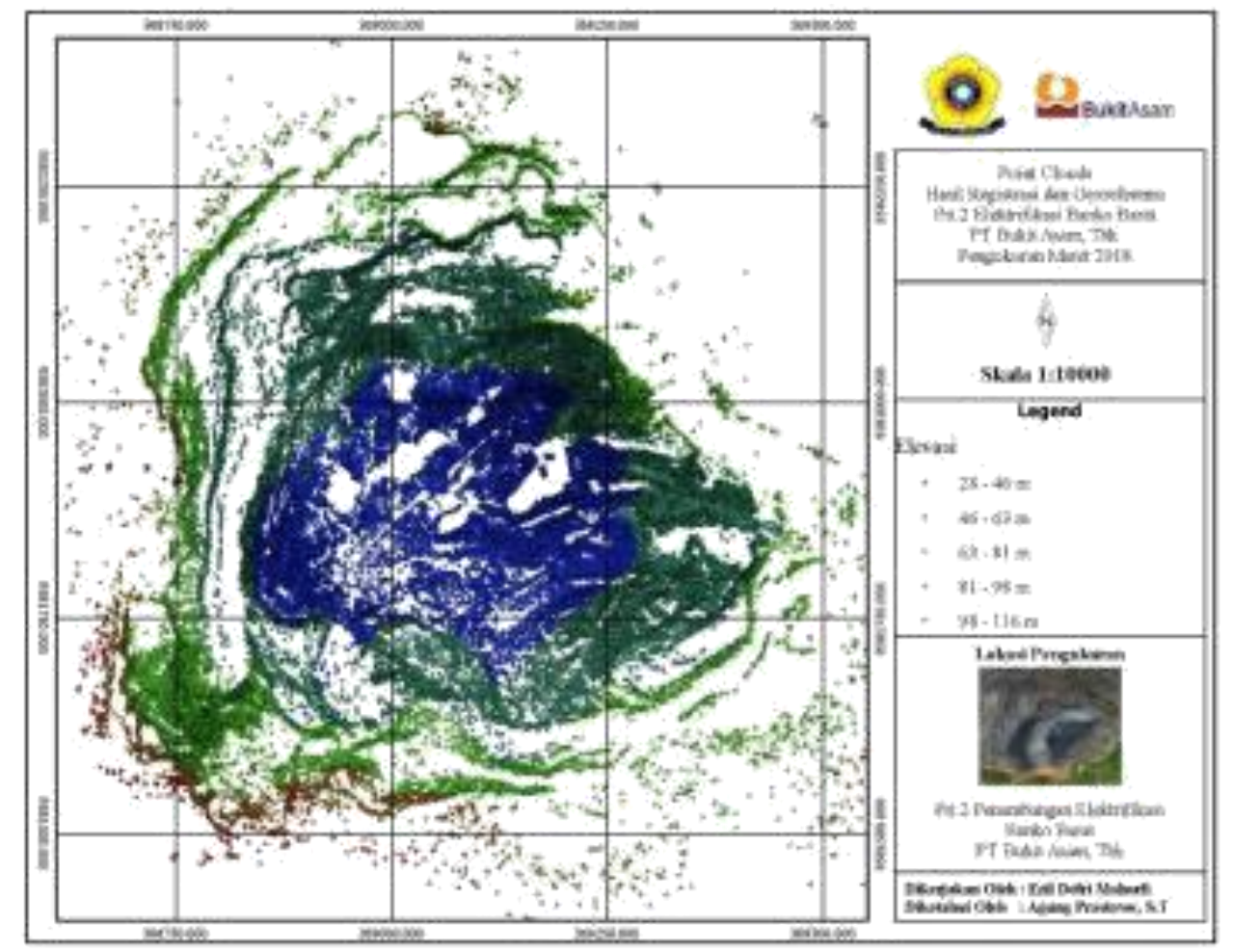

Gambar 9. Hasil Georeferensi data point clouds

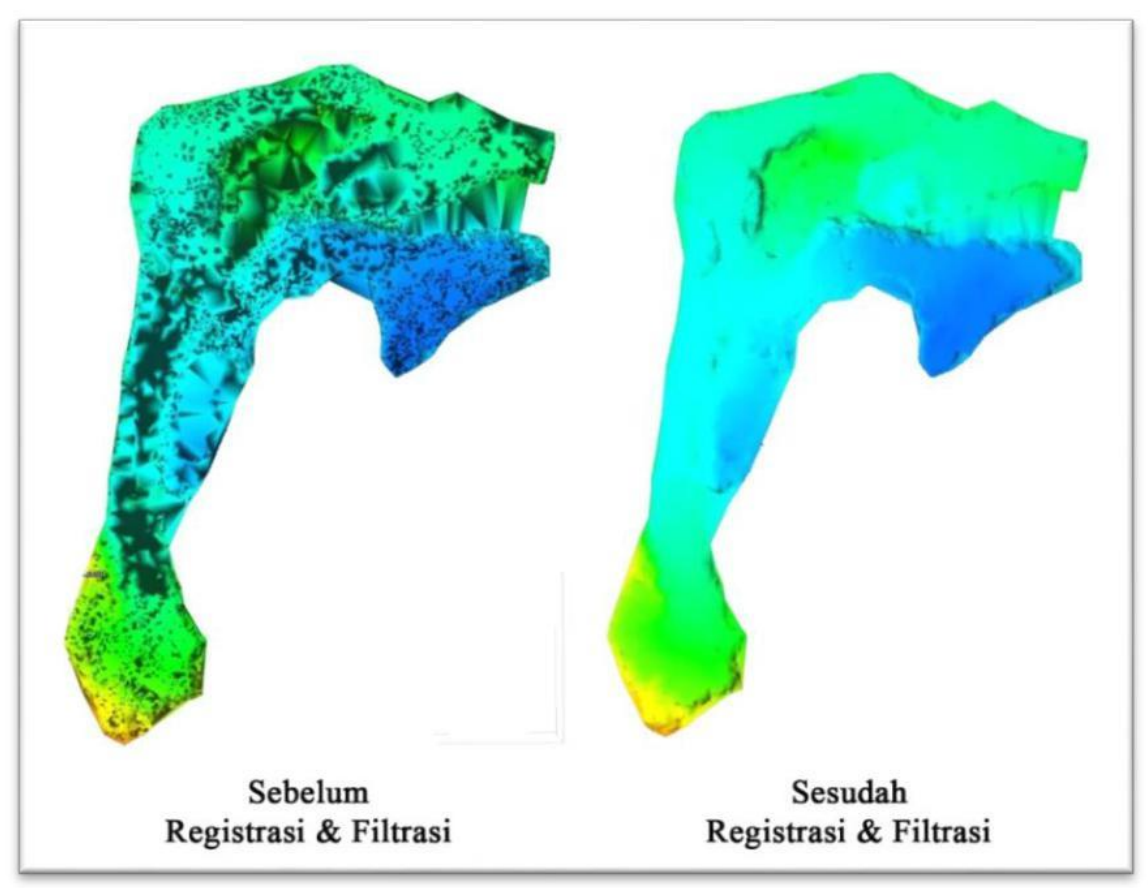

Gambar 10. Hasil tiga dimensi (3D) data point clouds

\subsection{Analisis Dasar Perhitungan Volume Pengupasan Overburden}

Perhitungan volume overburden pada software RiScan Pro menerapkan metode triangulasi, dimana metode ini merupakan bagian dari perhitungan volume endapan metode penampang horizontal. Metode triangulasi dilakukan dengan konsep dasar menjadikan titik yang diketahui menjadi titik sudut suatu prisma segitiga. Prisma segitiga diperoleh dengan cara menghubungkan titik-titik yang diketahui tanpa berpotongan.

Pada kasus perhitungan volume pengupasan overburden pada front penambangan, perhitungan didasarkan dengan membandingkan data pemodelan surface sebelum 
dengan sesudah dilakukannya pengupasan. Perhitungan volume pengupasan overburden dihitung berdasarkan data komulatif antara volume tanah yang terkupas (cut) dan volume tanah yang terisi (fill).
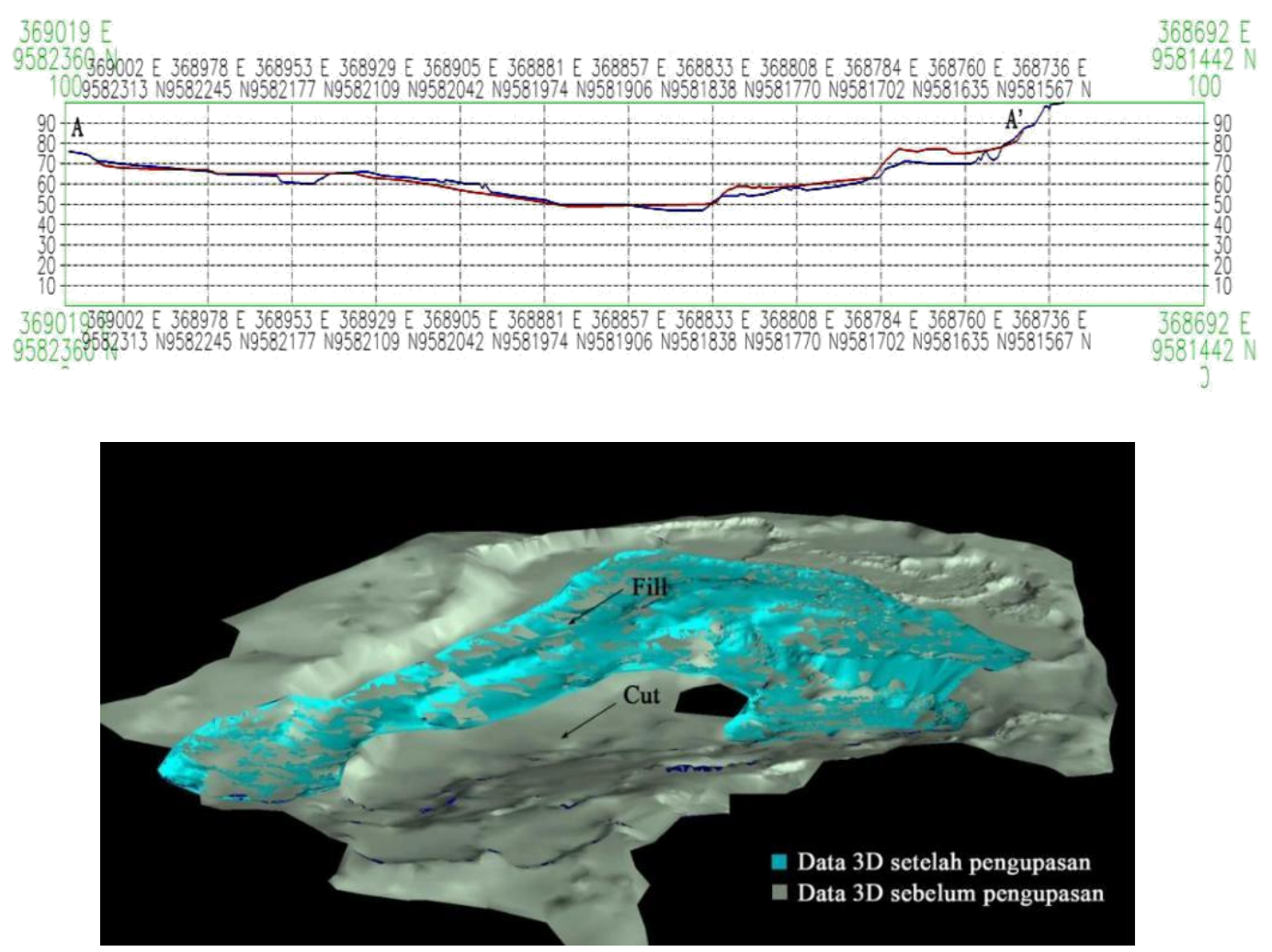

Gambar 11. Data perbandingan model 3D sebelum dan sesudah pengupasan overburden.

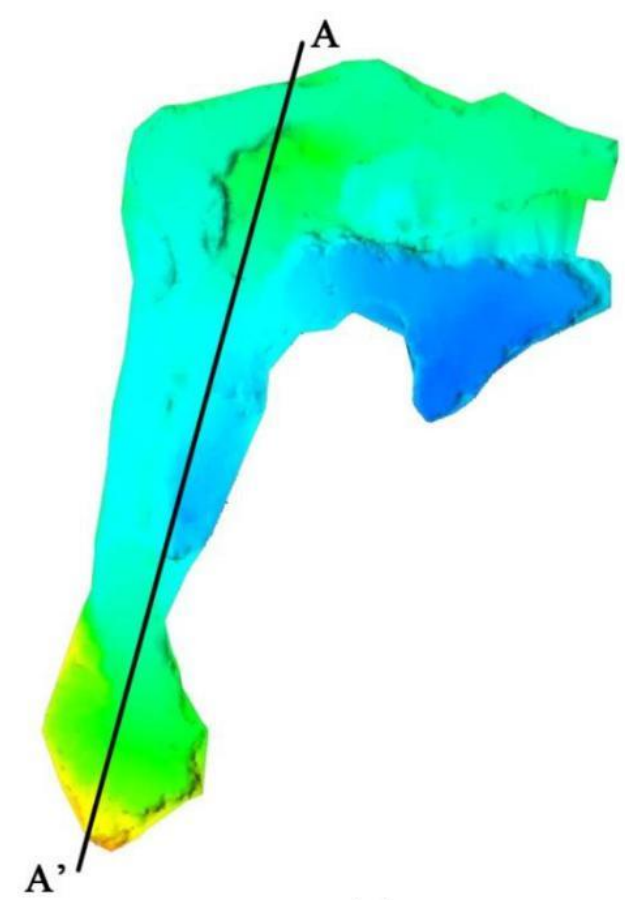

Gambar 12. Cross section untuk menunjukkan perbedaan elevasi sebelum dan sesudah pengupasan overburden 
Tabel 2. Volume Pengupasan Overburden Desember 2017 - Maret 2018

\begin{tabular}{|c|c|c|}
\hline \multicolumn{3}{|c|}{ Pengukuran Desember 2017} \\
\hline & Volume $C u t\left(\mathrm{~m}^{3}\right)$ & Volume Fill $\left(\mathrm{m}^{3}\right)$ \\
\hline Area Pengupasan 1 & 245500.19 & 11428.38 \\
\hline Area Pengupasan 2 & 22576.64 & 947.92 \\
\hline Volume Pengupasan Total OB (cut-fill) & & 255700.63 \\
\hline \multicolumn{3}{|c|}{ Pengukuran Januari 2018} \\
\hline & Volume $C u t\left(\mathrm{~m}^{3}\right)$ & Volume Fill $\left(\mathrm{m}^{3}\right)$ \\
\hline Area Pengupasan 1 & 336247.68 & 37127.02 \\
\hline Volume Pengupasan Total OB (cut-fill) & & 299120.65 \\
\hline \multicolumn{3}{|c|}{ Pengukuran Februari 2018} \\
\hline & Volume $C u t\left(\mathrm{~m}^{3}\right)$ & Volume Fill $\left(\mathrm{m}^{3}\right)$ \\
\hline Area Pengupasan 1 & 168340.36 & 7451.58 \\
\hline Area Pengupasan 2 & 68373.32 & 1718.63 \\
\hline Volume Pengupasan Total OB (cut-fill) & & 227543.46 \\
\hline \multicolumn{3}{|c|}{ Pengukuran Maret 2018} \\
\hline & Volume Cut $\left(\mathrm{m}^{3}\right)$ & Volume Fill $\left(\mathrm{m}^{3}\right)$ \\
\hline Area Pengupasan 1 & 53213.75 & 4334.26 \\
\hline Area Pengupasan 2 & 15199.55 & 225.46 \\
\hline Area Pengupasan 3 & 3406.62 & 1687.19 \\
\hline Volume Pengupasan Total OB (cut-fill) & & 65572.99 \\
\hline Volume Pengupasan OB Desember 2 & 2017 - Maret 2018 & 847937.74 \\
\hline
\end{tabular}

\subsection{Perbedaan Pengukuran Terrestrial Laser Scanner dengan Total Station}

Pengukuran menggunakan Total Station dilakukan dengan menegakkan Total Station dan sebuah prisma statis pada 2 titik kontrol (Benchmark) yang telah diketahui koordinatnya. Hal ini dilakukan agar arah utara Total Station sama dengan arah utara bumi. Prisma dinamis berfungsi sebagai penentu titik yang akan diukur koordinatnya. Perbedaan teknis pengukuran volume pengupasan overburden dengan menggunakan Total Station dan Terrestrial Laser Scanner dapat dilihat pada Tabel 3 .

Tabel 3. Perbedaan pengukuran antara Total Station dan Terrestrial Laser Scanner

\begin{tabular}{lll}
\hline & Total Station & Terrestrial Laser Scanner \\
\hline Bentuk Umum & Permukaan 3 Dimensi & Point Clouds \\
Detail Bentuk & Kurang Detail & Sangat Detail \\
& Berdasarkan ketinggian & Berdasarkan Ketinggian \\
Warna & Hitam Putih & Berdasarkan Jarak \\
& & Berdasarkan Intentitas \\
& & Warna Asli Objek \\
Penghalusan Bentuk & Otomatis & Melalui proses registrasi \\
& & dan filtering
\end{tabular}




\begin{tabular}{lll} 
& Total Station & Terrestrial Laser Scanner \\
\hline Pengambilan Titik & Manual & Otomatis (Laser) \\
Jarak Interval Titik & 10 meter & $15 \mathrm{~cm}$ \\
\hline Progres Bulanan & $3-6$ hari & $1-3$ Hari \\
Jumlah Surveyor & $4-5$ surveyor & 2 surveyor \\
Koding Objek & Manual & Tidak ada koding \\
\hline
\end{tabular}

\section{KESIMPULAN}

Berdasarkan pembahasan yang telah dilakukan dalam penelitian ini. Dapat diambil beberapa kesimpulan yaitu sebagai berikut :

1) Data point clouds front penambangan diperoleh dari hasil pengukuran dari Terrestrial Laser Scanner melakukan satu kali pemindaian tiap berdiri alat (scanworld). Titik berdiri alat (station) ditentukan pada area yang telah mengalami pengupasan. Koordinat station menjadi acuan Terrestrial Laser Scanner dalam mengukur tiap koordinat pada point clouds.

2) Penggabungan data point clouds menggunakan metode registrasi occupation and backsight dan metode cloud to cloud menghasilkan tingkat pertampalan yang mencapai $>80 \%$. Sehingga dapat disimpulkan bahwa penerapan metode ini tergolong dalam kategori akurat. Proses georeferensi dapat digunakan untuk menyelarasakan koordinat point cloudsdari koordinat lokal hasil pengukuran TLS dengan koordinat stasiun berdiri alatsehingga menjadi koordinat berdiri global yang sesuai dengan posisi sebenarnya di permukaan bumi.

3) Hasil perhitungan volume pengupasan overburden di Pit 2 Elektrifikasi Banko Barat, PT. Bukit Asam, Tbk pada periode Desember 2017 - Maret 2018 adalah sebesar $847937.74 \mathrm{~m}^{3}$, dengan rincian pada bulan Desember 2017 sebesar $255700.63 \mathrm{~m}^{3}$, bulan Januari 2018 sebesar $299120.65 \mathrm{~m}^{3}$, bulan februari 2018 sebesar $227543.46 \mathrm{~m}^{3}$, dan bulan Maret 2018 sebesar $65572.99 \mathrm{~m}^{3}$.

\section{DAFTAR PUSTAKA}

[1]Maharsayanto, P. Y. (2013). Aplikasi Terrestrial Laser Scanner Untuk Pemodelan Tampak Muka Bangunan. Tugas Akhir, Semarang : Jurusan Teknik Geodesi Fakultas Teknik Universitas Diponegoro.

[2] Kuang, S. (1996). Geodetic Network Analysis and Optimal Design : Concepts and Applications. Michigan: Ann Arbor Press, Inc

[3] Boehler, W. and Marbs, A., 2005, Investigating Laser Scanner Accuracy, i3mainz, Institute for Spatial Information and Surveying Technology, FH Mainz, University of Applied Sciences, Mainz, Germany.

[4] Hai, H. F. (2008). 3D Terrestrial Laser Scanning For Application In Earthwork And Topographical Surveys, University of Southern Queensland, Faculty of Engineering and Surveying. 
[5] Quintero, M. S., Genechten, B. V., M. D., Ronald, P., Hankar, M, dan Barnes, S., 2008, 3D Risk Mapping Theory and Practice on Terrestrial Laser Scanning, Vlaams Leonardo Da Vinci Agentschap, Europe.

[6] Pfeifer, N., 2007. Theory and Application of Laser Scanning, ISPRS Summer School 2007, Solvina.[7] Asdak, C. (1995). Hidrologi dan Pengelolaan Daerah Aliran Sungai. Yogyakarta:Gadjah Mada University Press.

[8] Basuki, Slamet, 2011, Ilmu Ukur Tanah, Gadjah Mada University Press, Yogyakarta

[9] Mochtar, 2012, Perbandingan Metode Registrasi Terrestrial laser scanner (Studi Kasus: Aula Timur dan Gardu Listrik GKU Timur), Bandung: Tugas Akhir, Jurusan Teknik Geodesi dan Geomatika, Fakultas Ilmu dan Teknologi Kebumian, Institut Teknologi Bandung, Bandung. 
